\title{
MARKETPLACE SEBAGAI MEDIA PEMASARAN PRODUK UKM DI KECAMATAN MAOS GUNA TINGKATKAN PEREKONOMIAN MASYARAKAT
}

\author{
Nur Wahyu Rahadi ${ }^{\# 1}$, Dwi Novia Prasetyanti ${ }^{\# 2}$, Artdhita Fajar Pratiwi ${ }^{* 3}$, Bayu Aji Girawan ${ }^{* 4}$ \\ \# Jurusan Teknik Informatika, Politeknik Negeri Cilacap \\ Jl. Dr. Soetomo No. 1, Sidakaya-Cilacap 53212 \\ ${ }^{1} \mathrm{n}$. wahyu.r08@gmail.com \\ ${ }^{2}$ dnpr4s3ty4nt1@gmail.com \\ "Jurusan Teknik Elektronika, Jurusan Teknik Mesin Politeknik negeri Cilacap \\ Jl. Dr. Soetomo No. 1, Sidakaya-Cilacap 53212 \\ 3 artdhita.pratiwi@gmail.com \\ ${ }^{4}$ bayuajigirawan@gmail.com
}

\begin{abstract}
Abstrak
Maos Lor merupakan salah satu desa yang memiliki banyak UKM dengan beberapa produk unggulan, antara lain batik, makanan khas, hasil pertanian serta perikanan. Produk yang dihasilkan akan dijual kepada masyarakat. Selain memanfaatkan pasar tradisional, masyarakat juga sudah menggunakan social media dalam menawarkan barang dagangannya. Pengalolaan kegiatan Pemasaran sebagian besar masih bersifat perorangan, sehingga hal tersebut dapat menjadi salah satu penyebab tidak meratanya tingkat perekonomian masyarakat. Sebuah wadah dalam bentuk sistem marketplace dapat dijadikan sebagai media Pemasaran, khususnya bagi masyarakat perorangan dan UKM. Sistem marketplace dapat digunakan untuk menawarkan produk yang dijual, memproses pembelian, konfirmasi pembayaran bahkan sampai pada informasi pengiriman barang, sehingga lebih banyak masyarakat yang dapat mengetahui produk-produk yang ditawarkan. Sistem tersebut dapat digunakan untuk mengelola produk-produk Pemasaran masyarakat dan UKM sebagai produk unggulan daerah tersebut. Pengelolaan penjualan produk UKM yang terpusat diharapkan dapat meningkatkan transaksi Pemasaran, sehingga dapat meningakatkan pendapatan yang berpotensi pada peningkatan tingkat perekonomian masyarakat.
\end{abstract}

Kata Kunci - Cilacap, Maos, Maos Lor, Marketplace, UKM.

\section{PENDAHULUAN}

Tingkat perekonomian masyarakat merupakan tolok ukur kemakmuran sebuah daerah. Salah satu kegiatan perekonomian yang dilakukan masyarakat adalah melalui pemasaran atau jual beli produk atau jasa. Pada proses penjualan, penjual atau penyedia barang dan jasa memberikan kepemilikan suatu komoditas kepada pembeli untuk suatu harga. Barang-barang atau jasa yang dijadikan komoditas pemasaran bermacam-macam, antara lain produk hasil pertanian, peternakan, perkebunan, perikanan, kerajinan, olahan dan masih banyak lagi. Produkproduk tersebut dapat dihasilkan oleh masyarakat secara perorangan, industri maupun kelompok masyarakat yang dapat dikatakan sebagai pengusaha skala kecil yang tergabung dalam UKM. Pengusaha skala kecil meliputi usaha kecil informal dan usaha kecil tradisional, usaha kecil informal merupakan usaha yang belum terdaftar, belum tercatat, dan belum berbadan hukum, yang termasuk dalam kelompok usaha kecil informal antara lain petani dan pedagang kaki lima, sedangkan usaha kecil tradisional merupakan usaha yang menggunakan alat produksi sederhana untuk pembuatan hasil olahan seperti pengrajin tanah dan kayu [1].

Kegiatan Pemasaran yang dilakukan masyarakat dilakukan melalui beberapa cara dan menggunakan sarana yang beragam. Pasar tradisional merupakan salah satu fasilitas umum yang digunakan masyarakat sebagai salah satu sarana untuk melakukan kegiatan Pemasaran. Selain memanfaatkan pasar tradisional, masyarakat juga sudah menggunakan social media dalam menawarkan barang dagangannya, sehingga dapat meningkatkan pendapatan.

Pengelolaan kegiatan Pemasaran yang dilakukan di Kecamatan Maos kabupaten Cilacap, sebagian besar masih bersifat perorangan, serta masih menggunakan media atau sarana antara lain pasar tradisional. Kondisi tersebut dapat 
menjadi salah satu penyebab tidak maksimalnya pendapatan yang diterima masyarakat serta tidak meratanya tingkat perekonomian masyarakat. Tidak maksimalnya pendapatan masyarakat mempengaruhi kemampuan masysrakat untuk menempuh pendidikan yang lebih tinggi serta tingkat perekonomian yang tidak merata dapat memicu kesenjangan sosial. Berbagai permasalahan juga dapat terjadi karena kondisi perekonomian yang tidak maksimal.

UMKM atau UKM dapat dijadikan sebagai salah satu wadah yang dapat menaungi semua pengusaha skala kecil baik perorangan ataupun kelompok. Produk yang dihasilkan oleh UKM tersebut dapat dipasarkan melalui marketplace, selain melalui sarana yang saat ini digunakan. Sistem marketplace dapat digunakan untuk menawarkan produk yang dijual, memproses pembelian, konfirmasi pembayaran bahkan sampai pada informasi pengiriman barang, sehingga lebih banyak masyarakat yang dapat mengetahui produk-produk yang ditawarkan. Sistem tersebut dapat digunakan untuk mengelola produk-produk Pemasaran masyarakat dan UKM sebagai produk unggulan daerah tersebut. Pengelolaan penjualan produk UKM yang terpusat diharapkan dapat meningkatkan transaksi Pemasaran, sehingga dapat meningakatkan pendapatan yang berpotensi pada peningkatan tingkat perekonomian masyarakat.

\section{TARGET DAN LUARAN}

Kecamatan Maos dipilih sebagai mitra pada kegiatan Pengabdian Kepada Masyarakat ini, karena Kecamatan Maos memiliki potensi yang cukup besar untuk meningkatakan pendapatan daerah [2]. Pemilihan Kecamatan Maos sebagai mitra, diharapkan dapat meningkatkan pendapatan, sehingga dapat meningkatakan tingkat kesejahteraan masyarakat.

Target luaran dari program ini berupa produk yaitu sebuah sistem marketplace berbasis webuntuk memasarkan produk-produk UKM yang terdapat di Maos. Dalam web site tersebut terdapat beberapa menu, antara lain yaitu beranda, menu pendaftaran UKM, data UKM, tambah produk, update produk, pembelian/pemesanan, konfirmasi pembayaran, serta kolom komentar, grafik penjualan, grafik jumlah anggota UKM, garfik produk. Penjelasan dari menumenu tersebut adalah sebagai berikut:

1. Beranda, berisi daftar menu yang ada dalam sistem marketplace tersebut.

2. Pendaftaran UKM berisi data-data UKM yang baru melakukan proses pendaftaran, untuk kemudian diberikan username dan password.
3. Data UKM, berisi semua profil UKM yang menjadi anggota marketplace.

4. Tambah produk, berisi data produk yang baru ditambahakan ke dalam sistem.

5. Update produk, merupakan menu yang dpat digunakan untuk melakukan pencarian produk untuk kemudian dilakukan update produk.

6. Pembelian/pemesanan, merupakan menu yang digunakan untuk melakukan pembelian produk yang dilakukan konsumen. Pada menu ini berisi data pembeli serta data produk yang dibeli.

7. Konfirmasi pembayaran, merupakan menu yag digunakan untuk melakukan konfirmasi setelah dilakukan pembayaran terhadapat produk yang dibeli. Pada menu ini terdapat data pembelian dan bagian upload bukti pembayaran.

8. Kolom komentar, merupakan menu yang dpat digunakan untuk memberikan penilaian bahkan masukan sebagai koreksi perbaikan bagi penjual ataupun bagi pengelola sistem.

9. Grafik penjualan, merupakan bentuk yang dibuat untuk mempermudah melihat perkembangan transaksi yang terjadi pada sistem marketplace ini. Grafik ini dapat mempermudah monitoring kegiatan transaksi penjualan.

10. Grafik jumlah UKM, merupakan bentuk pelaporan jumlah UKM yang tergabung dalam sistem ini.

11. Grafik produk, berisi informasi perkembangan jumlah produk yang dijual UKM dalam sistem ini.

Dengan menggunakan sistem marketplace ini, maka dapat memperluas jangkuan promosi, sehingga produk-produk yang dihasilkan UKM yang berada di Maos dapat lebih banyak diketahui oleh masyarakat luas, mempermudah UKM dalam memasarkan produk yang dihasilkan, dengan menggunakan biaya yang kecil. Kondisi tersebut memiliki potensi yang cukup besar dalam mendapatkan banyak konsumen yang berimbas pada meningkatnya pendapatan UKM. Selain menguntungkan bagi UKM, sistem ini juga dapat membantu pemerintah dalam mempromosikan produk unggulan daerah sebagai salah satu cara dalam meningkatkan perekonomian masyarakat.

\section{METODE PELAKSANAAN}

Pelaksanaan kegiatan Pengabdian kepada masyarakat ini dapat dibagi menjadi tiga bagian sebagai berikut:

1. Persiapan, pada tahapan ini, kegiatan-kegiatan yang dilakukan antara lain sebagai berikut:

a. Observasi, dilakukan dengan mengunjungi mitra secara langsung, yang diwakili oleh Kepala Desa Maos Lor.

b. Wawancara, dilakukan kepada Kepala Desa, untuk mengetahui kondisi, permasalahan serta kebutuhan mitra. 
c. Studi pustaka dilakukan dengan melakukan kajian pustaka berupa penelitian sebelumnya, tentang Kecamatan Maos.

a. Pelaksanaan, dilakukan dengan membangun sebuah sistem marketplace, dengan menggunakan metode pengambangan system Development Life Cycle/SDLC [3] yang meliputi langkah-langkah sebagai berikut:Planing, dalam tahap planing terdapat 2 langkah yaitu :

1. Feasibility berupa mengindentifikasi masalah, menentukan tujuan sistem, dan membuat studi kelayakan (teknik, operasional dan jadwal).

2. Sistem investigasi berupa observasi dan wawancara.

b. Analisis \& Requirement, dalam tahap analisis dibagi menjadi beberapa langkah antara lain :

1. Analisis informasi yaitu mengenai informasi-informasi tentang UKM, produk-produk yang dihasilkan, serta proses yang berjalan.

2. Analisis user yaitu menentukan kebutuhan user, dalam arti mengidentifikasi user yang akan menggunakan sistem.

3. Analisis teknologi yaitu menentukan kebutuhan-kebutuhan sistem baik dari software maupun hardware

c. Desain, pada tahap desain terdapat beberapa tahap, antara lain:

1. Model development merupakan model yang akan digunakan sebagai arsitektur sistem. Model ini menggambarkan relationship (hubungan) dari sistem keseluruhan, antara semua fungsi dalam modul yang terpisah, perubahan atau perpindahan data dari modul dalam sistem.

2. Desain database merupakan hubungan relasi antara Tabel dapat berupa normalisasi, dan menggambarkan secara detail masukan dan keluaran data.

d. Implementation, hasil dari implementation berupa prototyiping software. Prototype diuji dan disempurnakan sebelum dilakukan software tersebut implementasikan atau digunakan. Dalam software engineering, pembuatan prototype merupakan suatu proses produksi.

e. Pengujian, melakukan serangkaian ujicoba terhadap hasil dari implementasi aplikasi, dan memperbaiki jika masih terdapat kesalahan dan menarik kesimpulan dari analisis yang dilakukan.

Tahapan dalam pengembangan sistem dengan menggunakan metode SDLC dapat dilihat pada Gambar 1. Penerapan teknologi pada mitra dilakukan dengan kegiatan sosialisasi, pelatihan dan pendampingan.

1. Sosialisasi, dilakukan untuk mensosialisasikan sistem markerplace yang dihasilkan kepada mitra maupun kepada perwakilan dari masyarakat.

2. Pelatihan, dilakukan dengan mendemokan sistem markerplace, dilanjutkan dengan pengoperasian dan pengelolaan sistem markerplace.

3. Pendampingan, dilakukan dengan pengelolaan sistem marketplace oleh pengguna dengan tetap dilakukan pendampingan.

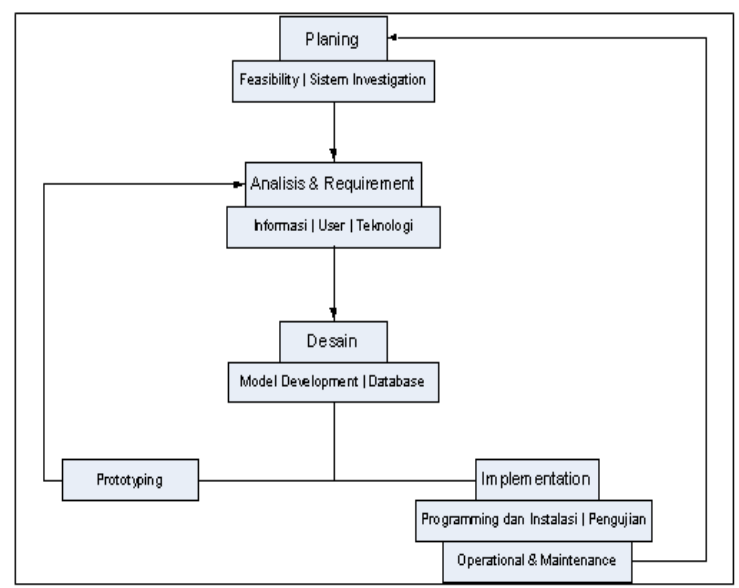

Gambar 1. Metode pengembangan SDLC

\section{HASIL DAN PEMBAHASAN}

Hasil dari kegiatan ini berupa aplikasi atau sistem marketplace. Berdasarkan tahapan yang dilakukan untuk menghasilkan sistem ini, perancangan pemesanan produk dapat dilihat pada Gambar 2 berikut ini:

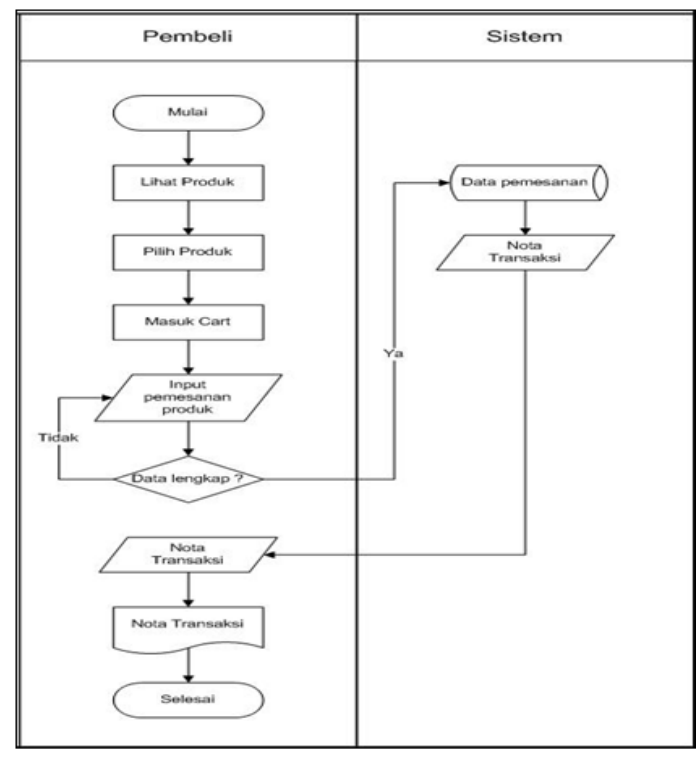

Gambar 2. Flowchart Pemesanan 
Transaksi pemesanan akan diikuti dengan proses pembayaran. Untuk melakukan konfirmasi pembayaran, maka berikut ini adalah flowchart konfirmasi pembayaran, seperti pada Gambar 3.

Data konfirmasi tersebut selanjutnya akan di cek oleh admin/karyawan apakah data tersebut valid atau tidak, jika tidak valid maka pembeli kembali melakukan konfirmasi pembayaran, kemudian jika data itu valid maka data pemesanan akan diperbarui status pembayarannya dan selanjutnya data pemesanan akan dikirim ke penjual

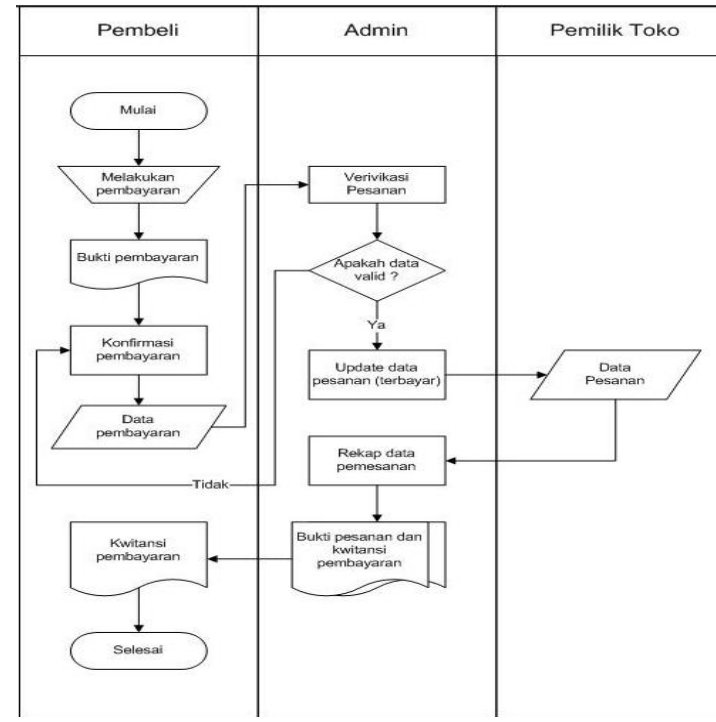

Gambar 3. Flowchart konfirmasi pembayaran

Sistem ini dapat diakses oleh pengguna, baik pembeli maupun penjual melalui website www.lapakmaos.com. Tampilan beranda dari aplikasi yang telah dibuat seperti yang tampak pada Gambar 4. Pada beranda ini terdapat link untuk melakukan pendaftaran bagi para UKM yang ingin bergabung.

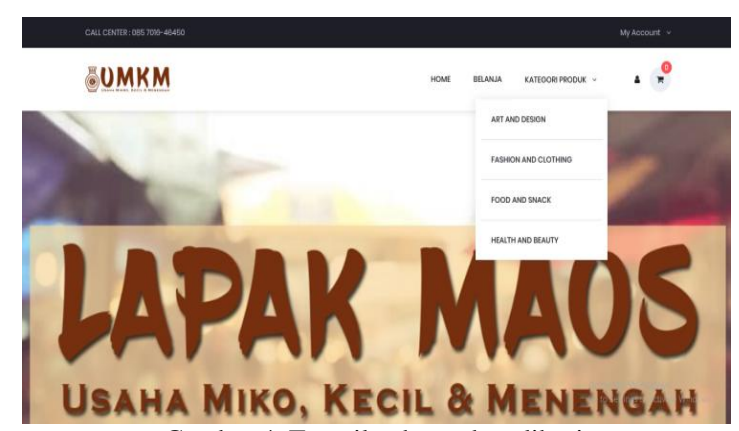

Gambar 4. Tampilan beranda aplikasi

Sistem ini memiliki beberapa fitur seperti yang telah dijelaskan pada bagian target dan luaran. Fitur tersebut antara lain adalah pengelolaan data member, seperti pada Gambar 5.

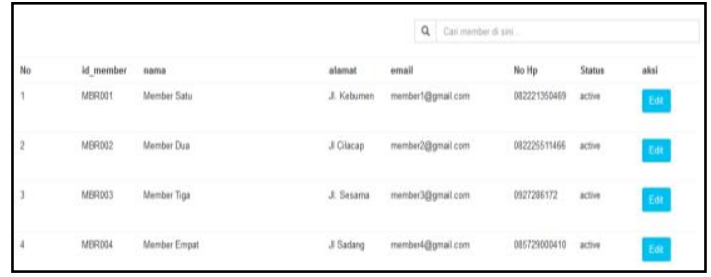

Gambar 5. Halaman data member

Member ataupun konsumen non member dapat melakukan pemesanan. Pemesanan tidak akan diproses sebelum dilakukan verifikasi oleh admin. Hasil verifikasi dapat berupa pesanan diterima atau pesanan ditolak. Pada Gambar 6 dan Gambar 7 berikut ini adalah tampilan pesanan diterima dan ditolak:

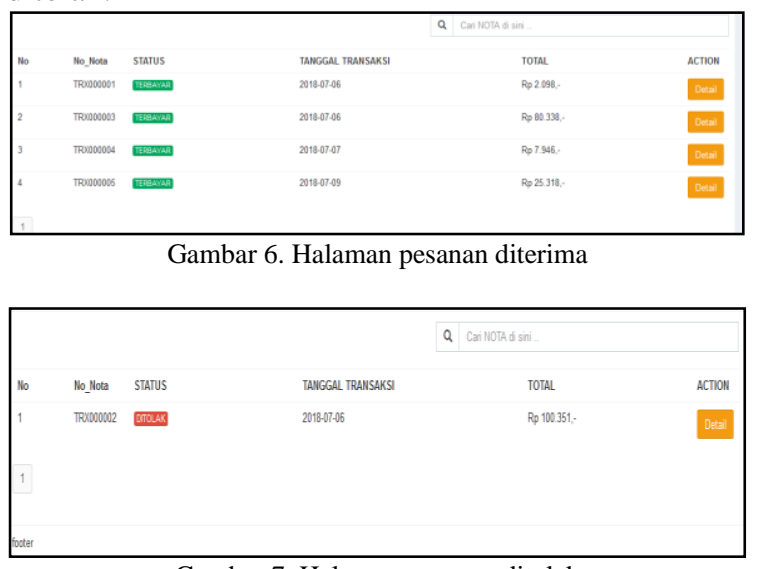

Gambar 7. Halaman pesanan ditolak

Perbedaan pesanan diterima dan ditolak terletak pada status pesanan. Selain itu dapat dilihat dari indikator warna. Warna hijau untuk pesanan diterima dan warna merah untuk pesanan ditolak.

Sistem marketplace yang dibuat telah disosialisasikan dengan baik kepada para pelaku dan pendamping UKM di daerah Kecamatan Maos, Desa Maos Lor. Sosialisasi yang diberikan sekaligus pelatihan tentang cara pengoperasaian sistem marketplace tersebut sebagai media pemasaran produk. Para peserta sangat antusias mengikuti dan mencoba mengoperasikan aplikasi tersebut, seperti yang terlihat pada Gambar 8 - Gambar 10 .

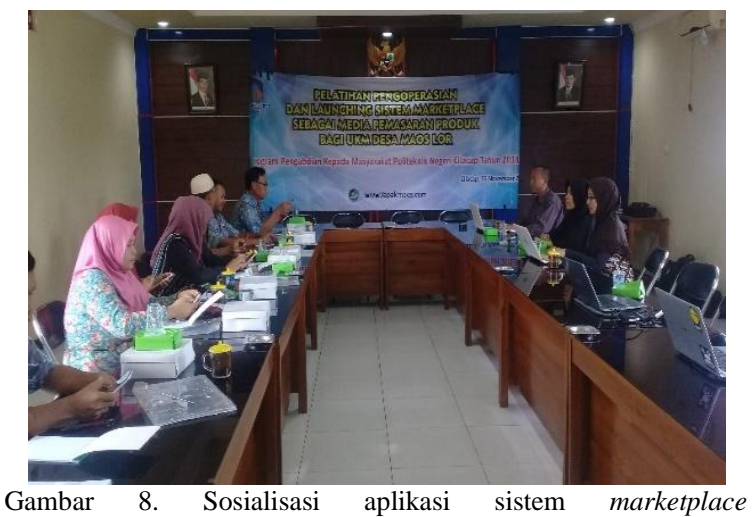




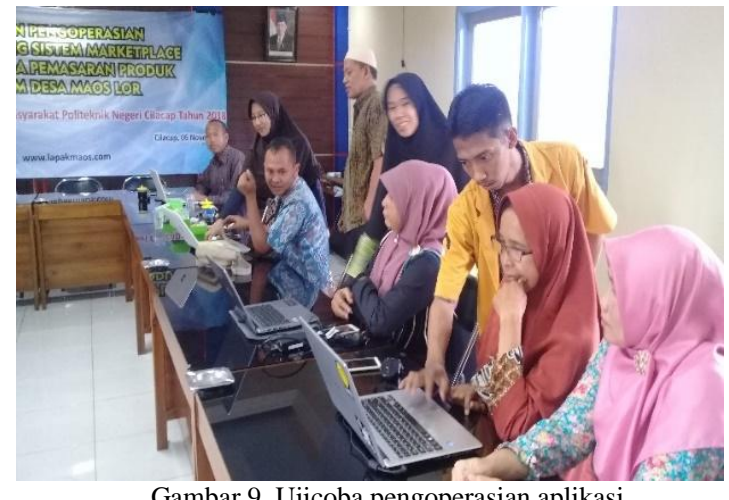

Gambar 9. Ujicoba pengoperasian aplikasi

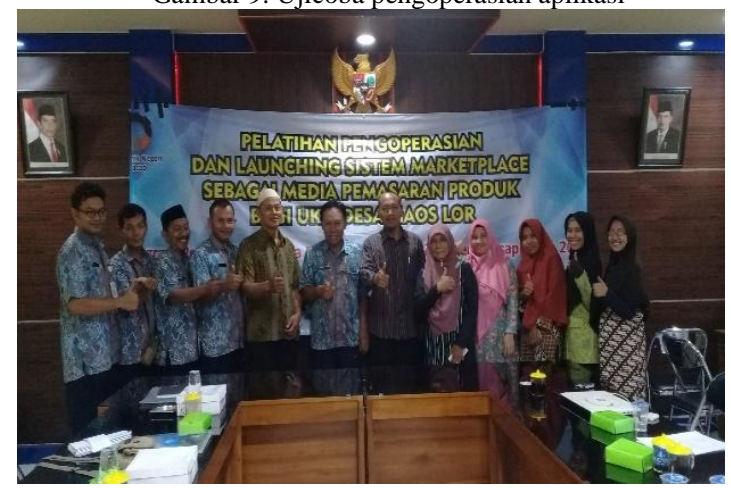

Gambar 10. Foto bersama dengan peserta pelatihan

\section{KESIMPULAN}

Berdasarkan kegiatan Pengabdian kepada Masyarakat yang telah dilakukan, kesimpulan yang dapat diambil adalah sebagai berikut :

1. Berdasarkan uji coba yang telah dilakukan sistem ini dapat membantu proses pengelolaan data transaksi pemesanan produk UKM.

2. Secara fungsional sistem ini dapat memudahkan dalam pemasaran produk UKM.

3. Sistem ini dapat memudahkan pada pengelolaan data produk UKM.

4. Sistem ini dapat meningkatkan kualitas pelayanan terhadap pembeli.

\section{UCAPAN TERIMA KASIH}

Kegiatan Pengabdian Kepada Masyarakat ini terlaksana karena dukungan dari beberapa pihak. Pada kesempatan ini, Pelaksana kegiatan Pengabdian Kepada Masyarakat menyampaikan rasa hormat dan terimakasih kepada Pusat Penelitian dan Pengabdian kepada Masyarakat (P3M) Politeknik Negeri Cilacap, atas pendanaan dan bantuan pada pelaksanaan kegiatan PKM ini. Selanjutnya Kepala Desa Maos Lor sebagai mitra dalam PKM ini. Terimakasih atas kepercayaan dan kerjasamanya, serta seluruh civitas akademika Politeknik Negeri Cilacap yang telah turut membantu kegiatan PKM ini.

\section{DAFTAR PUSTAKA}

[1] Irawan., 2014. Diakses pada 16 Agutus 2018 Asepirawan31.blogspot.com/2014/perusahaankecil.html?m=1\#

[2] Purwanto and Wahyuningsi., 2017. Inovasi Daerah dalam Pembangunan Desa Berbasis Potensi Desa. Jurnal Universitas 17 Agustus 1945 Surabaya, Surabaya.

[3] Connolly, Thomas M., Begg, Carolyn E., 2005. Database Systems, A Practical Approach to design, implementation and management. Fourth Edition. Addison-Wesley.

[4] A.S, Rosa and M.Shalahudin., 2013. Rekayasa Perangkat Lunak Terstruktur dan Berorientasi objek. Informatika, Bandung.

[5] Kadir, Abdul., 2013. Pemrograman Database MySQL Untuk Pemula Solusi Lengkap Pembuatan Aplikasi Web Menggunakan Php, JQuery dan CSS.Mediakom, Yogyakarta.

[6] Ladjamudin, bin Al-Bahra., 2005. Analisis dan Desain Sistem Informasi Edisi Pertama. Graha Ilmu, Yogyakarta.

[7] Nugroho and Bunafit., 2013. Dasar Pemrograman Web PHP-MySQL dengan Dreamweaver. Gava Media, Yogyakarta.

[8] O’Brien, James A. Marakas, George M., 2014. Sistem Informasi Manajemen Edisi 9. Salemba Empat, Jakarta.

[9] Purwanto and Yudhi., 2001 Pemrograman Web dengan PHP. Elex Media Komputindo, Jakarta.

[10] Simartama, Janner., 2010. Rekayasa Web. Penerbit Andi, Yogyakarta.

[11] Rizaldi, T., Setyohadi, D.P.S. and Riskiawan, H.Y., 2016. Implementasi Metodologi SCRUM dalam Pengembangan Sistem Pembayaran Elektronik Pada Usaha Mikro Kecil Menengah. Prosiding.

[12] Sutarman., 2007. Membangun Aplikasi Web Dengan PHP dan MySQL. Graha Ilmu, Yogyakarta.

[13] Wahyono, Teguh., 2004. Sistem Informasi Konsep Dasar, Analisis, Desain, dan Implementasi. Graha Ilmu, Yogyakarta. 